\title{
Salt Cooperatives as Public Credit Institutions for Coastal Communities: A Case Study of Two Salt Cooperatives in Rembang and Demak
}

\author{
Haryono Rinardi, * Yety Rochwulaningsih \\ Department of History Faculty of Humanities Diponegoro University
}

\begin{abstract}
By using the historical method, the study discussing the existence of salt-producing community public cooperatives as micro credit institutions growing among coastal communities in Rembang and Demak. Both similarities and differences exist between the two. Both institutions (cooperatives are in need of government assistance. Both exist as a result of the hard work dedicated by the managers. The difference lies in the attitude of the villages' administrators (bureaucrats)toward the existence of the cooperatives.
\end{abstract} Received: 5 June 2017 Accepted: 24 June 2017

*Corresponding author: haryonorinardi@undip.ac.id

Keywords: Salt cooperatives, village bureaucrats, micro credit institutions.

\section{Introduction}

The Pump Priming policy once adopted by the developmentalists in the second half of the twentieth century has not been proven to be entirely correct. The findings by Rinardi indicate that the low-interest (cheap) credits was not succeed in changing the social structure during 1904-1990. At least, number of causes are attributable to the failure of subsidized credits to improve small and middle size businesses are explainable. Cheap credits are oftentimes used as part of the interest of global industrialists. Second, the dominant economic sectors receiving such low-interest (cheap) credits are not those having strategic values for the economic development in Indonesia. There are almost always non-economic interests behind the policy of provision of small credits. Fourth, not all debtors of cheap or low-interest credits are able to benefit from the credits that they receive to improve their business performance. The needs for credits are not the only necessity for rural communities, including the small and middle size businesses, to be able to grow and develop. Sixth, the policy of providing cheap or low-interest credits is always ridden with corruption. ${ }^{1}$

Nevertheless, cheap or low-interest credits have been provided since the colonial era, Old Order, New Order, and continued to be provided up to the present. During the colonial era, the Government assigned the responsibility to the Volkcredietwezen to administer issues of credits or the natives. The cheap credit policy was again provided in the early years of the independence era. In 1950s, Bank Rakyat Indonesia was probably the only banking institution administering loans with a nominal value under one thousand (rupiahs). This banking institution

${ }^{1}$ Haryono Rinardi, “Kredit Untuk Rakyat: Kebijakan Kredit Kecil Perbankan untuk Usaha Kecil dan Menengah 1904-1990 (Ph.D dissertation, Gadjah Mada University, 2011), 532-533. 
also assisted farmer and the existence of village banks by providing services for small size credits. The policy of providing cheap or low-interest was later revived during the New Era. The so called Mass Guiding Program or Program Bimbingan Masal (Bimas) conducted in the early period of the New Era is one of the examples. Bimas was aimed at improving agricultural products by means of intensification in order to improve the welfare of farmers. ${ }^{2}$

All policies concerning the provision of low-interest credits are intended to improve the public welfare. In reality, however, the finacially weak people in Indonesia do not become prosperous, they continuously suffer financially. In the end, their welfare has not increased, if they do not suffer more. Volkscredietwezen did not directly provide capital to the people to do business, but it did facilitate the bureaucrats and elites in the villages to accumulate their wealth. ${ }^{3}$ The Bimas program, which was intended to create food self-suffiency and improve the farmers'welfare was only able to increase agricutural (food) products without improving the welfare of the farmers. The Government initiative to provide low-interest, cheap credits via the Bimas Program, intended to enable farmers to buy production facilities only ended up burdening the farmers (with the credits). Bimas credits even created deeper and wider gaps between the the rich farmers and the poor peasants. The Bimas credits benefited more to the rich farmers with fertile agricuktural land supported by good irigation system. ${ }^{4}$ More ironically still, Bimas credits were supposed to be responsible for the greater number of peasants, as more small-scale famers had to sell their paddy fields to pay for their debts. ${ }^{5}$

Thereby, the application of the pump primming policy to improve the farmers'welfare, specially those living in villages, was proven to have failed. The financial institutions used to provide loans to poor/financially less fortunate groups were used by the rural elites to enrich themselves. In some cases, however, there existed indications that rural-level credit institutions succesfully grew as the 'last resort' for the survival of rural communities. More interestingly, these credit institutions existed in the neghborhoods of coastal communities. These are interesting phenomena, because the pump priming policy has in so far been directed to rural community with ecology composed of paddy fields, not maritime ecology. The core of cheap or low-interest credits is farmers, not fishermen or people making a living by keeping fish in ponds (pond fishery).

These two successful credit institutions are Tri Daya Abadi Salt Cooperative (Koperasi Garam Tri Daya Abadi) existing in the Rembang and Garam Rakyat Sejahtera Cooperative (Koperasi Garam Rakyat Sejahtera) in the Wedung District, Demak. These two salt cooperatives have grown and prospered in in coastal areas, with customers consisting mostly of salt farmers. Both cooperatives do not receive direct assistance from the government. These two cooperatives grow and prosper because of the people's needs. Koperasi Garam Tri Daya Abadi has tried to collect salt farmers/farmers to sell their salt (to the cooperative) at the right time

${ }^{2}$ For further information, see; SK. Menteri Pertanian No. 546/Kpts/12/org/1969.

${ }^{3}$ Rinardi, "Kredit Untuk Rakyat", 492. See also Pandu Suharto, Sejarah Pendirian Bank Perkreditan Rakyat (Jakarta: Lembaga Pengembangan Perkreditan Indonesia, 1988), 81-82. See also; Verslag van het Volkscredietwezen 1920, 11.

${ }^{4}$ For further information; Jean Luc Maurer, "Beyond the Sawah: Economic Diversification in Four Bantul Villages, 1972-1987", edited by Paul Alexander et al., In the Shadow of Agriculture: Non-farm activities in the Javanese economy, past and present (Amsterdam: Royal Tropical Institute, 1991).

${ }^{5}$ Bimas Program only increases the number of peasants in. In 1973, the percentage of peasants accounts for $12.1 \%$, and in 1980 the number reaches $14.9 \%$. In other words, the number of peasants incrases after the BIMAS Program was implemented. For more information, see M. Dawam Rahardjo, Transformasi Pertanian, Industrialisasi dan Kesempatan Kerja (Jakarta: Universitas Indonesia Press, 1984), 44. See also; Chris Manning, "Penyerapan Tenaga Kerja di Pedesaan Jawa: Pelajaran dari Revolusi Hijau dan Bonanza Minyak, Prospeknya di Masa Depan" (paper presented at the Seminar Strategi Pembangunan Pedesaan, Yogyakarta, 1987), 20. 
and to the buyers also at the right time. In other words, the cooperative tries to remove the roles of salt middleman. By similar means, Koperasi Garam Rakyat Sejahtera has succeeded in raising the price of salt at the salt farmers prosperity level. The interesting aspect is that these two cooperatives provide credits for people who are enaged in the production and sale of salt. In other words, these two micro credit institutions serve maritime or coastal communities.

This fact indicates that the widely-known notion saying that coastal communities are unable to be guided (educated) only by establishing and empowering a credit institution or provider is untrue. The facts associated with the two cooperatives prove the opposite. The two credit institutions in Rembang and Demak grow and develop among coastal or maritime communities. Both have grown and prospered not by the support or assistance from the top or the government. It is the communities' initiatives to empower the resources that they own that make these two cooperatives grow.

Based on these findings, it may be concluded that micro credit institutions are able to grow and prosper or develop in coastal communities. Therefore, an interesting to be observed here is how a micro credit institution can grow and prosper in a coastal area and what factors have made these two cooperatives reach the success in assisting to improve their customers' economy. Their success serves as an exemplary idea on how the form and structure of credit institutions at rural level successfully improving the people's economy should be.

\section{Method}

The method used in this article is a combination between historical and observation methods. These two methods are used because a part of the study is concerned with events of the past and therefore the historical method must be used to acquire the historical data and facts. The observation method is used because the events discussed in other part are those taking place more recently and the observation method must therefore be applied to find out how such event has occurred and what changes have taken place and processed.

\section{Credits in the Coastal Communities}

In general, the people receiving the credits are rural communities living mostly in the hinterland. In otherwords, they are ecologically villagers who are paddy field farmers/cultivators. For this purpose, the government has tried to provide an access to capital for the coastal communities by establishing Micro Financial Institutions (LKM). These financial bodies were originally social institutions not having the status of a legal entity, called Lembaga Ekonomi Pengembangan Pesisir Mikro Mitra Mina (LEPPM3). In its course, the LEPPM3 was later legalized to be able to grow better, in cooperation with banking institutions for managerial consulting and information technology. In this case, the role of LKM was the mediator for credits between the banking institutions and the communities/people. The many complicated requirements for applying for credits to be complied with by the people could be simplified by the LKM and the communities are then able to receive credits with relatively easy requirements. The LKM eventually became one of the alternative solutions upon which these coastal people rely via the two-step mechanism involving the banking institution. The coastal residents, previously not feeling confident to apply for credits with LKM now slowly gained their confidence after finding out that the requirements were actually simple. LKM only serve micro-scale credits for coastal people, credits under Rp. 50 million. It is recorded that until 2007, 256 LKM units had been set up, 6 of which were in the form of Coastal People's Credit Bank or Bank Perkreditan Rakyat (BPR) Pesisir, 
in the regencies of Agam, Pesisir Selatan, Pasuruan, Bima, Lombok Barat and Selayar, respectively. ${ }^{6}$

The problem is that not all regions were fortunate enough to receive the credits via the existence of the LKM. Nonetheless, the government tried to assist people by supporting the establishments of LKM in different locations, via various activities. ${ }^{7}$ The participation of the people was required to grow and dvelop LKMs in line with their needs. This participation was important because people, including fishermen and fish-pond fishermen were and are not bankable individuals, which makes it difficult for them to receive credits through formal banking institutions. The credits allocated to them were/are much smaller compared to those profided for middle-class business people or conglomerates. ${ }^{8}$ Nevertheless, there were LKMs in coastal communities which had grown and developed to serve the needs for credits and to support the economy of their customers.

\section{Rural Credit Institution: A Case study of Tri Daya Abadi Salt Cooperative}

Tri Daya Abadi Cooperative has original Indonesian name as Koperasi Garam Tri Daya Abadi, it is the registered name of the micro/rural credit institution established as a pilot project for the development of rural micro credit institutions. Since its formation, Koperasi Tri Daya Abadi has been successful in forming its management. Elected as its head is Budi Istanto, who is the Village Head of Gedong Mulyo, District of Lasem. The Cooperative's Secretary is Nur Salim, the Village Head of Punjulharjo, District of Rembang. The Cooperative's Treasurer is Sudjarwo, who is the Village Head of Dasun, District of Lasem, Regency of Rembang. The first management of this cooperative was initially held by village heads of these three villages, representing the core organ of the cooperative establishment. This is understandable as the establishment of the cooperative was fully supported by the initiatives of these three village heads.

Another encouraging thing is that Koperasi Tri Daya has been able to acquire its deed of establishment under notarized deed Number 173, dated 25 September 2013. With this notarized deed of establishment, the status of Koperasi Tri Daya Abadi is legal under the laws. Thereby Koperasi Tri Daya can operate legally and is not considered as an illegal organization. This favourable condition assists the cooperative to develop its business as a production cooperative.

This cooperative is classified as a production one, producing salt as state in its registered name. Koperasi Tri Daya Abadi is domicile in the sub-district of Gedong Mulyo, District of Lasem, Rembang. Its membership, however, is not limited to people residing in the sub-district of Gedong Mulyo. It is open to all people, particularly those who are living in Rembang. The requirements for becoming members Koperasi Tri Daya as formally stated are Indonesian citizens capable of performing legal actions, meaning an adult and is not under legal custody.

The members of Koperasi Tri Daya do not only come from the village of Gedong Mulyo. Some of them also come from the village of Punjulharjo, District of Rembang and Dasun, District of Lasem. This structure of membership is natural as the three villages are adjacent and directly share borders. More interestingly, these three villages have a lot of salt ponds or fields because they are located on a coastal area. In its progress, however, some members come from outside of the three villages. The reason underlying this fact is that, in principle, Koperasi Tri Daya Abadi is open for all Rembang residents. There is an important factor that makes the members of

${ }^{6}$ M. Zaki Mahasin, "PEMP Teramputasi Birokrasi Keuangan," Samudera, 12 October 2008, accessed 23 January 2015. http://majalahsamudra.at.ua/news/2008-12-10-3.

${ }^{7}$ Haryono Rinardi, et al., "Perkembangan LKD Tasik Agung Sebagai Institusi Kredit Mikro 2005- 2015", Laporan Akhir Hibah Kompetitif Fakultas, 2016, 1.

${ }^{8}$ For more information, see; http://www.harianhaluan.com accessed 27 January 2015. 
Koperasi Tri Daya Abadi come from several villages. The management of this cooperative is very flexible in implementing the Articles of Association of this cooperative, Koperasi Tri Daya Abadi. They give tolerance to people who intend to become members of the the cooperative but do not have sufficient fund as stated in the cooperative's Articles of Association.

Koperasi Tri Daya Abadi was established through the discussion for approval taking place in the Village Hall of the Sub-district of Dasun held on 10 January 2013. The discussion was attended salt farmers in the three villages, Punjul Harjo, Dasun, and Gedong Mulyo. Further, the discussion for approval elected Budi Istanto, who is the Village Head of Gedong Mulyo, as the head, Nur Salim, the Village Head of Punjul Harjo as the Secretary, and Sujarwo, the Village Head of Dasun, as the Treasurer of the cooperative. In its progress, the organization of this cooperative was later supplemented with the cooperative's supervisor. The cooperative organizational structure is as follows Joko Supeno (as head), Akhsan and Siti Juwariyah (as member).

Tri Daya Abadi has flourished in the last two years. The net profit that it has obtained is more than Rp. 40 million, with its salt in stock accounting for twelve to thirteen tons. ${ }^{9}$ The fund (profit) is deposited by the management in a bank. This condition reflects that during the period of two years, the management of the cooperative (in this case, the management) has worked hard. On the other hands, this condition indicates that the cooperative will potentially grow further, if well managed. The financial records and capital of the cooperative indicates that cooperative's management is careful in managing the cooperative. This careful management is indicated by the fund amounting to more than Rp. 40 million deposited in the bank. This fund can be beneficial when used to buy salt owned by its members. In that way, the cooperative has assisted its members to receive cash. The members no longer sell their salt to the middleman or brokers at low prices.

In relation to that condition, the management argues that they (the management) are not able to buy all the salt produced by the members. This inability is caused by number of factors. First, the fund generated from the profit gained by the cooperative is limited to Rp. 40 million, an amount insufficient to buy all the salt harvested by the salt farmers because salt harvests are still in progress. Any buyer purchasing salt from the harvest of a certain salt producer will result in jealousy from the other salt farmers. Second, the quality of the salt harvested by the salt farmers is not equal. The quality of all the salt produced by the cooperative's members is compatible to the market's expectation. Therefore, the management must be careful in purchasing the salt produced by its members. They should consider that the salt that the cooperative purchase must be able to be sold on the market. All these actions are based on the cooperative's management sustainability. This carefulness is associated with one of the provisions contained in the cooperative's Articles of Association stating that the management is liable to any losses suffered by the cooperative, as result of their negligence. Based on that provision, the cooperative's management must be careful in performing their actions regarding cooperative concernss. The management is not speculative in buying the salt produced by the cooperative's members. The quality of the salt may not be or is not compatible to the standards required by the market.

In so far, the cooperative has utilized the facilities owned by its members. The cooperative does not have a storehouse large enough to accommodate the salt purchased from its members. The store room or warehouse provided as an aid by the government is unable to accommodate all the salt purchased by the cooperative from its members. The management, therefore, use the store rooms or warehouses owned by the members, especially members of the

9Interview with Sujarwo, the treasurer of Koperasi Tri Daya Abadi, 6 September 2015. 
management, to store the cooperative's salt. For this reason, it can be said that the cooperative is not yet managed professionally.

This condition is understandable because the existence of the cooperative is less than two years. The management has struggled a lot for the cooperative's interest. They operate the cooperative based on their own consciousness and, at the same time, as their devotion to others. They have struggled and made sacrifices in managing the cooperative to make it grow and develop. It is not surprising that in the different activities conducted by the cooperative, from the annual meeting (held for the latest time on 15 January 2015) to the various and other meetings, the managers have had to use their own personal money to make such meetings successful. ${ }^{10}$ In this aspect, there are some ideas related to the management of the cooperative. Same parties (of the members) suggest that the cooperative's managers be given a salary, with the hope that they will work professionally and thereby the cooperative will grow better, and the end results, the people who are the cooperative's members will acquire the maximum results from its operation.

Although still have managerial difficulty, the cooperative received aids in the form of salt miller from the Regional Office of Industrial, Trade and Cooperative Affairs in 2014. This assistance has enabled the cooperative to provide an added value to the salt purchased from its members. Koperasi Tri Daya Abadi has been able to receive or draw supports from INDAKOP for the salt farmers in the eastern regions of Rembang. Various aids for salt farmers can be received from INDAKOP other parties or agencies. This condition has become fresh air for the salt farmers in eastern Rembang as the aids also have always been received by salt farmers lived in the western Rembang. Included in the aids are geoisolator and warehouse to store the salt produced by the cooperative's members. This way, the members have indirectly received the supports from the government, something that the salt farmers in eastern Rembang have never received before.

Like any small and middle size businesses in Indonesia in general, Koperasi Tri Daya Abadi is facing capital and marketing problems. ${ }^{11}$ The policy taken to overcome problems related to capital is its reliance on the compulsory contributions from the members. The member's contributions, however, cannot be relied upon, considering their own financial conditions. In relation to the marketing, the cooperative has built relationships with third parties considered to capable of buying from salt farmers by the cooperative's members. This effort is now being initiated by the cooperative's managers, with the hope to create networks with third parties who can purchase the salt owned by the cooperative.

The first step to create networks with third parties is to prepare Memorandum of Understanding (MOU) with the members who will act as the salt suppliers for the cooperative. The main point to be considered is that the quality of the salt produced by the members must comply with the quality standard required by the market. Regarding this issue, the cooperative has continuously tried to give the understanding and knowledge to its members so that they will produce salt with the quality as required by the market. This requirement is not actually a serious problem because the colour and cleanliness of the salt produced in Rembang are sufficiently good. The problem is how to maintain the quality of the products when the salt farmers are under pressure to produce much more salt. In such a case, they tend to sacrifice the quality for the quantity. This is unfavorable practice has been prevented by the cooperative to make sure

\footnotetext{
${ }^{10}$ Interview with Nur Salim, the secretary of the Koperasi Tri Daya Abadi, 6 September 2015.

${ }^{11}$ One of the problems faced by small and middle size businesses in Indonesia is the capital and marketing of the products. For clearer information, see Huib Poot et al., Industrialisation and Trade in Indonesia (Yogyakarta: Gadjah Mada University Press, 1992), 207.
} 
that the salt from the cooperative is continuously consistent with the requirements set by the buyer.

Tri Daya Abadi, like small and middle size business in Indonesia in general, also faces problems with the working capital to enable it to grow. As a result, not all the salt produced by its members can be purchased by this cooperative. This condition is certainly unfavorable for both the cooperative and its members. Under the economic pressure, salt farmers may have to sell their salt at a low price. This will cause the salt productions to be sold at low price, lower than market price. In the end, the salt farmers will al ways suffer as they must accept much lower prices for their productions. On the other hand, this condition indicates that the cooperative has failed to show its role as a price controller or price-maintaining agent, as initially intended.

Regarding on marketing matters, since its early existence the cooperative has made efforts to supply salt to all PKK (Women's Family Welfare Association) organizations in Rembang. This endeavor almost succeeded 2014, but finally failed because the salt to be supplied was not compatible to the requirements set out by the PKK. One of the requirements to be fulfilled by the supplier was the cleanliness of salt and should using a salt cleaner, operated with certain standards. In this case, the cooperative did not have the necessary salt cleaner. ${ }^{12}$

\section{Garam Rakyat Sejahtera Cooperative}

Koperasi Garam Rakyat Sejahtera located in the village of Kedung Mutih, Wedhung district, Demak. It was established in February 2015. Thereby, its performance may not be compared to that of Koperasi Tri Daya Abadi. This cooperative was established under Notarized Deed Number 291/BH/XIV/8/II/2015. As such, Koperasi Garam Rakyat Sejahtera is formally established. With its legal status, this cooperative can operate in the regions of the Regency of Demak. It is able to sell and buy salt from its members. The profit generated from the difference of the salt buying and selling price. Koperasi Garam Rakyat Sejahtera buys salt when the price is still low. Nonetheless, they always buy salt from the members at a price higher than that of the market or that offered by the middleman or brokers. In this way, they can set the price higher at the level of salt farmers. When the salt price rises, usually taking place in the rainy season, they will sell the salt. In this way, Koperasi Garam Rakyat Sejahtera can gain profits and, at the same time, improve the members' welfare. Buying salt at a price higher the the market price or that offered by the brokers may indirectly trigger the price rise at the level of salt farmers. The salt farmers are no longer victimized by the brokers or middleman. They will be able to enjoy a higher price for their salt and thefore they can increase their income, which in turn will increase the salt farmers' welfare of Kedungmutih.

Unlike Koperasi Tri Daya Abadi, which is fully supported by the Village Heads of three villages, Punjul Harjo, Dasun, and Gedong Mulyo, the existence of Koperasi Garam Rakyat Sejahtera is almost without any support for its village bureaucrats. The management of Koperasi Garam Sejahtera has even been challenged by its village bureaucrats. They are considered as young men without any proper experience and know nothing about cooperative issues. ${ }^{13}$ This negative view made the bureaucrats of Kedungmutih unable to five supports to the establishment and development of Koperasi Garam Rakyat Sejahtera. They even inclined to be hostile toward the existence of this cooperative because the existence of Koperasi Garam Kedungmutih was and is not in line with the desires of the village's bureaucrats.

\footnotetext{
${ }^{12}$ Interview with Priyadi, Advisor of Koperasi Tri Daya Abadi, 6 September 2015. Eventually, salt cleaners were given to the salt cooperative for salt farmers in the western areas of Rembang.

${ }^{13}$ Interview with Rofi'i, Head of Koperasi Garam Sejahtera, 30 Agustus 2015.
} 
With such unfavorable backgrounds, the management of this cooperative have worked in their own initiatives. They do this all with the hope that the cooperative, Koperasi Garam Rakyat Sejahtera, is able to grow and develop/flourish. Through this cooperative, the managers and members hope that the welfare of the people of Kedungmutih will improve. This consciousness has made the managers make "sacrifices" for the growth and development of Koperasi Garam Rakyat Sejahtera. Some of the activities done by the Koperasi Garam Rakyat Sejahtera have been conducted and financed with the personal funds of the managers, including the expenses to attend trainings on salt cultivation at a regency level, and also for the travels to visit a number of salt-producing centers located outside the Regency of Demak. All these steps have been taken for the development of Koperasi Garam Rakyat Sejahtera. In the opinion of the managers, if this salt cooperative can grow well, then the people of the village of Kedungmutih will automatically join them. So, making sacrifices for the development and progress of the cooperative is not a burden for them. They do this all sincerely and all the sacrifices made are dedicated to the development of this salt cooperative, which, in turn, will increase the welfare of the people of Kedungmutih, who mostly work in salt ponds.

Koperasi Garam Rakyat Sejahtera already has a complete management, consisting of the Head, Supervisor, and cooperative manager, who properly manage the operation of the cooperative. The cooperative manager manages the cooperative as per its Articles of Association/Articles of Corporation. The cooperative manager is responsible for the Management of the cooperative under its Articles of Association, supporting and improving the cooperative, improving the services concerning the salt business operated by the cooperative, and more importantly, the cooperative manager performs all legal actions on behalf of the cooperative, including to represent the cooperative inside and outside the court. The cooperative's management must prepare and present the work plan, the cooperative's budget of its incomes and expenses. Another important duty of the Cooperative's Management is to hold the Members' Meeting and to be responsible for the implementation of the management of the cooperative. The organizational structure of the Management of Koperasi Garam Rakyat Sejahtera; Head is Rofi'in; Secretary is Nur Ahwan; and Treasurer is Teguh.

These three persons are the key managers of Koperasi Garam Rakyat Sejahtera. In serving their duties, the managers are responsible for the operation of the cooperative. The cooperative manager does not work alone, he is assisted by number of personnel. The complete organizational structure of the management of Koperasi Garam Rakyat Sejahtera is as follows (1) Manager given to Noor Khotib; (2) Marketing Manager is Muhammad Saiq; (3) Purchasing Manager belongs to Hasan. The purchasing manager is assisted by four personnel, they are Turkhamim, Nur Syaidin, Zamroni, and Mukrodin. This cooperative is also supplemented by a supervisor whose duties are (1) To provide the managers with advice and supervision; (2) To supervise the implementation of the policies and management of the the cooperative conducted by the management; (3) To report the results of the supervision to the Members' Meeting

The supervisory board of Koperasi Garam Rakyat Sejahtera is composed of three persons, the head and two regular members. These persons are Parni (as head), Ali Mas'ud and Hamim (as member). With the hard work and dedication of the managers, the management and its members, Koperasi Garam Rakyat Sejahtera has been able to accumulate more than ten million Rupiahs in a short period of time (until September 2015).

The fund has been generated from the members' compulsory contributions, amounting to Rp. 7.3 million and, more importantly, the remaining is from the profits generated from the sale and purchase transactions of the salt owned by the members. With the successful accumulation of fund amounting more than ten million Rupiahs solely generated from the profits, it can be said that Koperasi Garam Sejahtera has a relatively good performance. 
Koperasi Garam Rakyat Sejahtera has also received assistance from the government. The assistance is allocated for the members and the operational equipment of the cooperative. The aids received by the members are in the form of geo-isolator as the base layer in salt production. This assistance is very important for the salt farmers because they can produce whiter and cleaner salt with better salt crystals. The problem is that the number of the geo-isolator given by the Regional Government of Demak is still limited, and consequently not all members of the cooperatives have received the assistance and only few of them have been able to enjoy the assistance. As a result, only little of the salt farmers by the cooperative's members is in good quality. Most of the salt produced by the cooperative's members is in poor quality, as the colour is less than clear and the crystals are not large enough.

Another assistance given by the Regional Government of Demak is the funding for the construction of the salt warehouses or storerooms. This assistance is given to enable the cooperative to have the storage facilities so that it can to store the salt purchased from the salt farmers during the great harvests. With the assistance for building warehouses or storerooms, the cooperative may operate more flexibly and buy salt from its members in greater quantities. In this way, the price of salt produced in Kedungmutih will not drop drastically during the saltharvesting seasons. This is one of the cooperative's purposes, serving as a price-maintaining agent at the local level. When the price of salt rises, the cooperative will sell the salt stored in the warehouses or storerooms.

There are, however, some problems to be addressed to the development of Koperasi Garam Rakyat Sejahtera Kedungmutih. First, the problem is associated with the geographical condition of the cooperative in Kedungmutih itself. The soil in Kedungmutih is mostly composed of muddy soil, including the land used as salt ponds. Consequently, the salt produced in Kedungmutih is less white in colour. Salt cleanliness or colour of salt is in fact one of the indicators of the quality of salt. For this rason, the quality of the salt from Kedungmutih considered to be poor.

The second problem is related to the ability or skills of the salt farmers in making salt. Compared with the salt farmers of Rembang, the skills salt farmers in Kedungmutih making salt in can be said to inferior. The salt produced by the salt farmers in Rembang is better. Consequently, the sale price is also higher and that of the salt produced in Kedungmutih. The skills of the salt farmers are a separate issue to be dealt with and solved, in order develop to Koperasi Garam Rakyat Sejahtera. If the salt farmers have better skills in producing better quality salt, the cooperative will be able to gain greater profits. The salt bought and sold by the cooperative will be valued higher, which results in increased profits received by the cooperative.

The third problem is related to the infrastructure existing in the village of Kedungmutih. Geographically, this village is remotely located. The transportation of salt from the ponds to the warehouses or storerooms, and later to the buyers, is quite a problem. The access must be better considered. The salt must be transported fast, from the warehouses or storerooms to the buyer(s) because salt is a weather-vulnerable commodity, particularly heavy rain and flood. Consequently, it requires the support from various parties to make the access more easily used to distribute the salt from Kedungmutih to buyers, free from the disturbance caused by heavy rain and flood.

The fourth problem connected with the lack of support from the village bureaucrats toward the cooperative. This is a vital aspect because without the full bureaucratic support the cooperative will face various difficulties to receive the aids from the government. So, an approach to the bureaucrats must be made in so that they will be willing to provide assistance to the cooperative. 


\section{Salt Cooperative: Their Future Development}

For inter-related reasons, salt cooperatives are required by salt farmers. First, people need financial institutions like cooperatives as price-maintaining agents so that the price of salt will not drop deeply during the times of great harvests. Second, the first condition is closely related to the subsequent factor in that salt farmers generally have a very limited capital so they need to sell their products as soon as practically possible to meet their basic needs. This condition has led to the fact that the trade of salt has been traditionally controlled by middleman or brokers. These intermediary traders/brokers dictate the price of salt. Salt farmers are generally unfortunate, unskilled and financially weak (low-graded human resources) and are therefore in need of guidance, both technical and managerial. Fifth, the assistance from the government is only given via cooperatives. Therefore, the existence of salt cooperatives serves as a solution to enable people to receive the various aids from the government, including the technical equipment, Human Resources development and marketing.

Despite the fact above mentioned, learning from the two salt cooperatives, we notice that some aspects need to be considered. First, rural cooperatives require active guidance and supervision from the government. This necessity is reflected in the case of Koperasi Garam Tri Daya Abadi. The government aids facilitated the cooperative to exist and develop in the future. As in the case of Koperasi Garam Tri Daya Abadi the role of one of the INDAKOP staff members is vital. There are two sectors particularly must be assisted. First, the development of human resources and provision of the equipments. Second, rural cooperatives require active participation from the village's bureaucrats. These two salt cooperatives have different relationships with the village's bureaucrats. Koperasi Garam Tri Daya Abadi is fully supported by the village's bureaucrats. As a result, many aids and development from the government have been easily acquired. On the other hand, Koperasi Garam Sejahtera does not have a good relationship with the village's bureaucrats, so they (the managers) have had to actively take steps to obtain the assistance from the government and the PUGAR. Third, it can be concluded that, after learning from these two cooperatives. A salt cooperative requires a specific credit scheme for its growth or development. They need cash to enable them to buy the salt produced by their members during the great harvests. Cash is necessary to prevent the salt price dropping drastically in salt farmers level. In this case, it is important to design a credit suitable scheme correctly compatible with the cooperative's needs and financial condition. This credit scheme must be seasonal in nature, as it is needed only during a great harvest. The credit will be repaid during the rainy season when the salt from the salt farmers is sold at an increased price.

The development of salt cooperative requires clean, honest, and smart managers to develop credit institution. This condition is necessary because cooperative managers are the first persons involved in the development of the institution. The success and failure of a cooperative are often determined by them. They are the individuals who manage the funds raised from the members of a cooperative. Moreover, they also manage different aids from the government to be used by the cooperative's members. For this reason, the managers of a cooperative have central roles in developing the institution. On the other hand, good supervision is needed for cooperative to grow. The lesson learned from the colonial era is that the government is fully aware any credit institution, in whatever form, cannot grow without good supervision. ${ }^{14}$

Cooperatives require guidance and supervision from the relevant authority, either the regional government or a special institution. This condition is primarily related to technical issues

\footnotetext{
${ }^{14}$ Verslag van het Volkscredietwezen 1925, 5.
} 
in salt business. This issue connected with the resources owned by a salt cooperative. Learning the lesson from the case of Koperasi Garam Sejahtera it is found that all human resources being the salt farmers need to be improved. The guidance and technical assistance from INDAKOP and PUGAR help the cooperative's members to obtain better salt production training. On the other hand, a supervisory institution is needed, either to guide or to supervise the cooperative I order to avoid mismanagement or corruption. ${ }^{15}$ Moreover, the supervisory institution will also function to open the possibility to help the development of the cooperative, for example by recommending to the government to provide additional capital.

The attest point is crucial because salt cooperatives are widely known to have insufficient capital to buy the salt produced by their members. This condition is associated with the cash needs for survival. Therefore, with sufficient funds a cooperative will be able to buy the salt from the salt farmers when harvest come with higher price rather than offered by brokers. By That way, the price of salt will not drop to the lowest level during the salt harvests. In the end, if cooperative can gain profits at the end of the rainy season then part of the profits can be distributed to its members.

\section{Conclusions}

The Pump Priming policy has not always failed to serve as the solution in developing villages in Indonesia. Some cases show that the pump priming policy gives positive results for both the people and the institutions providing micro credits. The cases of Koperasi Tri Daya Abadi and Koperasi Garam Rakyat Sejahtera show their successes in improving the economy of communities. The two cooperatives have been able to manage and develop the fund from the people as the initial working capital for rural-level credit institutions. The fund is well managed and therefore the amount has increased. On the other hand, the members gain benefit from this institution.

There is government participation in developing both cooperatives, although the role is limited. The members and customers of the two cooperatives hope that the government will pay attentions and assist salt cooperatives. The assistance may not be in the form of cash but opportunity to product market. In other words, marketing network is required by salt farmers who are members of salt cooperative.

\section{References}

Rinardi, Haryono. "Kredit Untuk Rakyat: Kebijakan Kredit Kecil Perbankan untuk Usaha Kecil dan Menengah 1904-1990. Ph.D dissertation, Gadjah Mada University, 2011.

Maurer, Jean Luc. "Beyond the Sawah: Economic Diversification in Four Bantul Villages, 19721987." In the Shadow of Agriculture: Non-farm activities in the Javanese economy, past and present, edited by Paul Alexander et al. Amsterdam: Royal Tropical Institute, 1991.

Rahardjo, M. Dawam. Transformasi Pertanian, Industrialisasi dan Kesempatan Kerja. Jakarta: Universitas Indonesia Press, 1984.

Manning, Chris. "Penyerapan Tenaga Kerja di Pedesaan Jawa: Pelajaran dari Revolusi Hijau dan Bonanza Minyak, Prospeknya di Masa Depan." Paper presented at the Seminar Strategi Pembangunan Pedesaan, Yogyakarta, 1987.

${ }^{15}$ Rural-level credit institutions always require supervision and guidance to enable them to grow well. For detailed information, read Rinardi, Kredit Untuk Rakyat, 494-495. See also; MVO Residen Banten W.C.H. Thime 1920, Reel No. 2 Serie 1e, ANRI Collection. Read; MVO Residen Tegal 1930, Reel No. 4 Serie 2e, ANRI Collection. MVO Residen Banten C.W.A. van Riensum 1913, Reel No. 1 Serie 1e, ANRI Collection. 
Mahasin, M. Zaki "PEMP Teramputasi Birokrasi Keuangan." Majalah Samudera, 12 October 2008. Accessed 23 January 2015. http://majalahsamudra.at.ua/news/2008-12-10-3.

Rinardi, Haryono et al., "Perkembangan LKD Tasik Agung Sebagai Institusi Kredit Mikro 20052015", Laporan Akhir Hibah Kompetitif Fakultas Ilmu Budaya Undip, 2016.

http://www.harianhaluan.com/. Accessed 27 January 2015.

Poot, Huib et al., Industrialisation and Trade in Indonesia. Yogyakarta: Gadjah Mada University Press, 1992.

Verslag van het Volkscredietwezen 1925, 5.

MVO Residen Banten W.C.H. Thime 1920, Reel No. 2 Serie 1e, ANRI Collection.

MVO Residen Tegal 1930, Reel No. 4 Serie 2e, ANRI Collection.

MVO Residen Banten C.W.A. van Riensum 1913, Reel No. 1 Serie 1e, ANRI Collection.

\section{List of Interviews}

Interview with Sujarwo, Treasurer of Koperasi Tri Daya Abadi 6 September 2015.

Interview with Nur Salim, Secretary of Koperasi Tri Daya Abadi, 6 September 2015.

Interview with Priyadi, Advisor of Koperasi Garam Tri Daya Abadi, 6 September 2015.

Interview with Rofi'i, Head of Koperasi Garam Sejahtera, 30 Agustus 2015. 